\title{
Numerical Analysis of Hansenula, Pichia and Related Yeast Genera
}

\author{
By I. CAMPBELL \\ Department of Brewing and Biological Sciences, \\ Heriot-Watt University, Edinburgh EHI I $H X$
}

(Received 28 December 1972; revised 5 March 1973)

\begin{abstract}
SUMMARY
Numerical analysis of published standard descriptions of the eight species of Debaryomyces, 48 species of Pichia and the single species of Wingea failed to distinguish separate genera. It is proposed that they be combined as a single genus Pichia of 4I species, three of which were formerly allocated to the genus Endomycopsis. The genus Hansenula, of 20 species including Pachysolen tannophilus and three former species of Endomycopsis, is closely related to the genus Pichia and is distinguished only by the ability of Hansenula species to assimilate nitrate. In the genus Schwanniomyces the number of species is reduced from four to two, and in Lipomyces, from three to one.
\end{abstract}

\section{INTRODUCTION}

The taxonomy of the genus Pichia was examined by Poncet (1957) by factor analysis of single strains of each species. Kreger-van Rij (1969) criticized the representation of species by a single strain, since many species showed wide variations in properties. A similar study was undertaken of the genus Hansenula (Poncet, I970), again by analysis of single strains of each species. The genera Hansenula and Pichia were re-examined, as in an earlier analysis of Kluyveromyces and Saccharomyces (Campbell, 1972), by analysis of the descriptions of species provided by Wickerham (I970a) and Kreger-van Rij (I970a), and by authors who have subsequently described new species of these genera. In this way, all known variations between strains were considered. Poncet's analyses were limited to the genera Pichia and Hansenula. In this present report, other genera known (Lodder, 1970; Campbell, 197I) or suspected to be similar to Hansenula and Pichia are also included: Citeromyces, Debaryomyces, Dekkera, Endomycopsis, Lipomyces, Lodderomyces, Pachysolen, Schwanniomyces and Wingea. Although it was initially intended to limit the analysis to sporing yeasts, the imperfect equivalent of Dekkera, the genus Brettanomyces, was easily included.

\section{METHODS}

Characters for numerical analysis. The system for analysis of the genus Saccharomyces (Campbell, I972) was modified to deal with the different range of properties under examination: 58 characters described by Lodder (1970) were examined, as follows.

Morphology (I8 characters). Pellicle (two characters) absent $(--)$, thin and weak $(+-)$ or well developed $(++)$; capsule or slime (one character); spores (five characters) I to $2(+-), \geqslant 3(-+)$ or I to $\geqslant 3(++)$ per ascus, spherical/oval $(+--)$, hat $(-+-)$ or Saturn $(--+)$ shaped. Colony (two characters) and cell (five characters) morphology, 
and formation of pseudomycelium (two characters) were as described previously (Campbell, I972).

Physiology (40 characters). The number of tests was determined by those properties common to all standard descriptions, e.g. splitting of arbutin and resistance to cycloheximide were omitted from Wickerham's (I970a) standard descriptions of Hansenula species and were therefore not used in the analyses. Fermentation was assessed as six characters: glucose, galactose, sucrose, maltose, $\frac{1}{3}$ raffinose and $\frac{2}{3} /$ complete raffinose. Fermentation of melibiose was disregarded, being automatically included in complete fermentation of raffinose. Assimilation of carbon sources, other than glucose, provided 30 characters, and the data were completed by four additional tests: assimilation of nitrate, growth in vitamindeficient media, in $10 \% \mathrm{NaCl}+5 \%$ glucose or in $50 \%$ glucose (regarded for this analysis as equivalent tests of osmophily) and at $37{ }^{\circ} \mathrm{C}$. The matching coefficients, $S_{8}$ (Sneath, 1972), between strains was determined from both positive and negative matches (Campbell, I970) by computer programs I and 2 (Campbell, 1970, 1973) and the results were expressed in dendrogram form at highest mutual similarity level expressed to the nearest $5 \%$ (Campbell, I970).

\section{RESULTS}

Because a single analysis of all genera involved an extremely large number of species, two separate groups of genera were tested in preliminary analyses. The resulting clusters were then compared.

Numerical analysis of standard descriptions of Ambrosiozyma, Debaryomyces, Endomycopsis, Pichia, Schwanniomyces and Wingea species

The standard descriptions analysed included eight species of Debaryomyces (Kregervan Rij, 1970 b), 36 of Pichia (Kreger-van Rij, 1970a), ten of Endomycopsis (Kreger-van Rij, I970c), four of Schwanniomyces (Phaff, 1970) and one species of Wingea (van der Walt, I970a). The following recently described species were also included: Endomycopsis muscicola Nakase \& Komagata (1966), Pichia ambrosiae van der Walt \& Scott (I97I $a$ ), $P$. besseyi Kurtzman \& Wickerham (1972), P. cicatricosa Scott \& van der Walt (I97Ia), $P$. crossotarsi Batra (1971), P. heimii Pignal (1970), P. melissophila van der Walt \& van der Klift (1972), $P$. microspora Batra (1971), P. mucosa Wickerham \& Kurtzman (1971), $P$. nonfermentans Nakase (197I), $P$. sargentensis Wickerham \& Kurtzman (1971), $P$. spartinae Ahearn, Yarrow \& Meyers (I970) and $P$. xylopsoci van der Walt \& Scott (I97I $b$ ). Ambrosiozyma philentoma van der Walt et al. (van der Walt, 1972) was included because of its close association with species of Endomycopsis and Pichia. Pichia faecalis (Batista \& Silveira) de Queiroz (1970) was regarded as synonymous with $P$. etchellsii (Kreger-van Rij, $1970 a$ ) and was therefore not examined.

Five main groups were distinguished, mutually related at $70 \%$ matching coefficient (Fig. I). Fifteen Pichia species and two Endomycopsis species related to Pichia membranaefaciens formed the first group; 7 species of Pichia, and possibly also $P$. media which was difficult to allocate to a taxonomic group, five of Endomycopsis and Ambrosiozyma philentoma formed a second group, of which the main species were Endomycopsis fibuligera and $P$. guilliermondii. Eight species of Pichia and four of Endomycopsis formed a poorly defined third group. Five species of Pichia were associated with Wingea robertsii and seven Debaryomyces species in the fourth main group. The genus Schwanniomyces, related at $70 \%$ matching to the Debaryomyces group, was related at approx. $65 \%$ matching to the other groups of Pichia and Endomycopsis. It is interesting that the Debaryomyces group is composed entirely of species which form spherical and usually warty spores (see Kreger-van Rij, 
I970 $a, b$ ); in other groups of the genus Pichia only P. fluxuum, P. kudriavzevii and $P$. terricola, and occasionally four other species of the $P$. membranaefaciens group, form such spores (Kreger-van Rij, I970a).

Following the precedent of our analysis of the genus Saccharomyces (Campbell, 1972), species related at $S_{\mathrm{s}} \geqslant 90 \%$ were considered synonymous, and therefore the 68 species of Ambrosiozyma, Debaryomyces, Endomycopsis, Pichia and Wingea in this analysis were reduced to 50 valid species. The four species of Schwanniomyces (Phaff, 1970) were reduced to two.

Numerical analysis of standard descriptions of Brettanomyces, Citeromyces, Dekkera, Hansenula, Lipomyces, Lodderomyces and Pachysolen species

The standard descriptions of the 25 species of Hansenula described by Wickerham (I970 a) were analysed, i.e. including the two species also classified as Endomycopsis (Kregervan Rij, $1970 \mathrm{c}$ ). To that group were added seven species of Brettanomyces (van der Walt, I970 ), two species of Dekkera (van der Walt, I970 c), three of Lipomyces (Slooff, 1970), Citeromyces matritensis (Wickerham, I970 b), Lodderomyces elongisporus (van der Walt, I970 d) and Pachysolen tannophilus (Wickerham, 1970 c). The following recently described species were included in the analysis: Brettanomyces abstinens Yarrow \& Ahearn (I97I), B. naardenensis Kolfschoten \& Yarrow (1970), Hansenula dryadoides Scott \& van der Walt (I97I b), H. muscicola (Nakase \& Komagata) Yarrow (I972), H. philodendra Scott \& van der Walt $(1970 a)$ and $H$. sydowiorum Scott \& van der Walt (1970b). Hansenula malanga Dwidjoseputro \& Wolf (1970) was not included since the standard description could not be fitted into the Lodder (1970) pattern.

The genera Citeromyces, Hansenula and Pachysolen were clearly related (Fig. 2), forming two main groups related at $\mathrm{S}_{8} 70 \%$. In a group of 20 species which contained Citeromyces matritensis and Pachysolen tannophilus, six species were closely related to Hansenula polymorpha, and four capsulate or slime-forming species formed a separate subgroup. The remaining Hansenula species formed a group of ten species at $S_{s} 80 \%$ in which the major species were $H$. anomala, $H$. saturnus and $H$. subpelliculosa.

Species of Brettanomyces and Dekkera were arranged in two groups: the two species of Dekkera and six species of Brettanomyces formed a homogeneous group equivalent to a single species, Brettanomyces abstinens Yarrow \& Ahearn, B. custersianus and B. naardenensis Kolfschoten \& Yarrow formed a group at $\mathrm{S}_{\mathrm{s}} 75 \%$, separated at $70 \%$ matching coefficient from the main group of Brettanomyces. Lodderomyces elongisporus was placed at $S_{8}$ $65 \%$ with Brettanomyces and Hansenula.

The genus Lipomyces was unlike the other genera of this series of tests, being related at approx. 60 to $65 \%$ matching to the other groups. The three species of Lipomyces included a $20 \%$ variation, and overlapped so extensively as to be indistinguishable by numerical analysis.

\section{Combined analysis}

Having determined the main groups of clusters in the two groups of genera (Fig. I, 2), the analysis was completed by a series of comparisons in which each species was compared with all others. The results were confirmed by comparison of the main groups detected and illustrated in Fig. I and 2. Fig. 3 shows these results in dendrogram form. A large cluster at $\mathrm{S}_{8} 70$ to $75 \%$ included the genera Citeromyces, Endomycopsis, Hansenula, Pachysolen and Pichia. Brettanomyces, Debaryomyces and related Pichia species, Dekkera, Lipomyces, Lodderomyces, Schwanniomyces and Wingea (included in the Debaryomyces hansenii group) were related to the $70 \%$ cluster and to each other at $65 \%$ matching. 


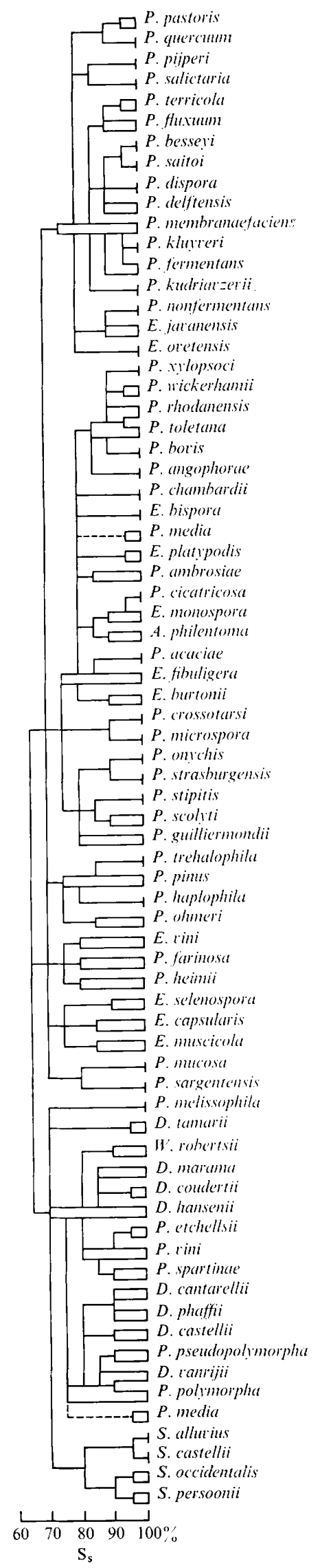

Fig. I

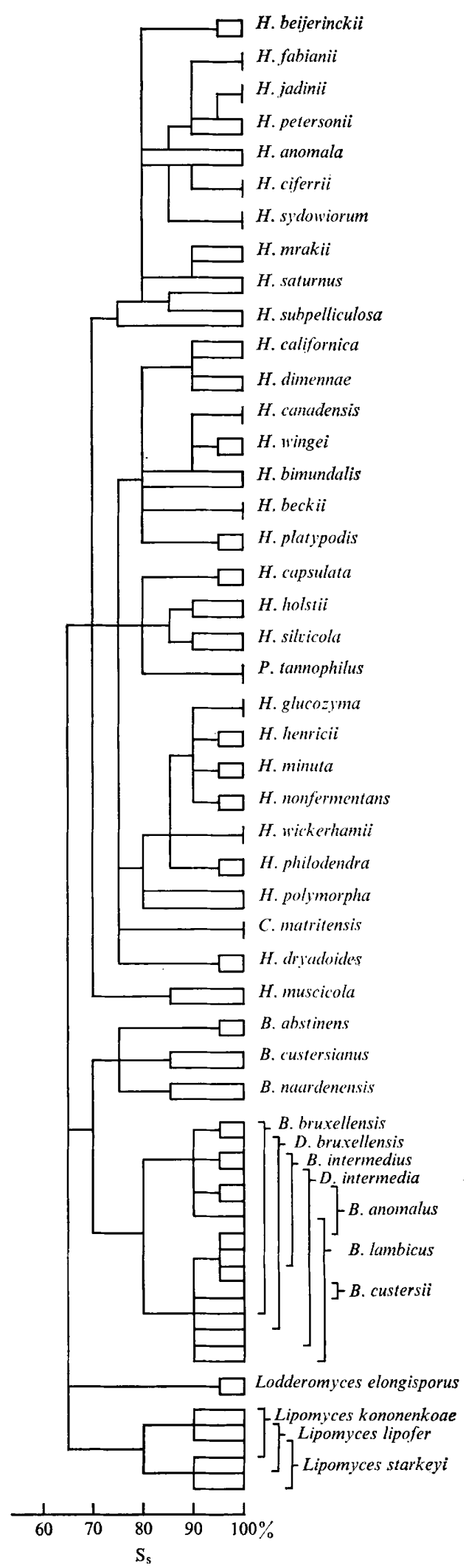

Fig. 2 


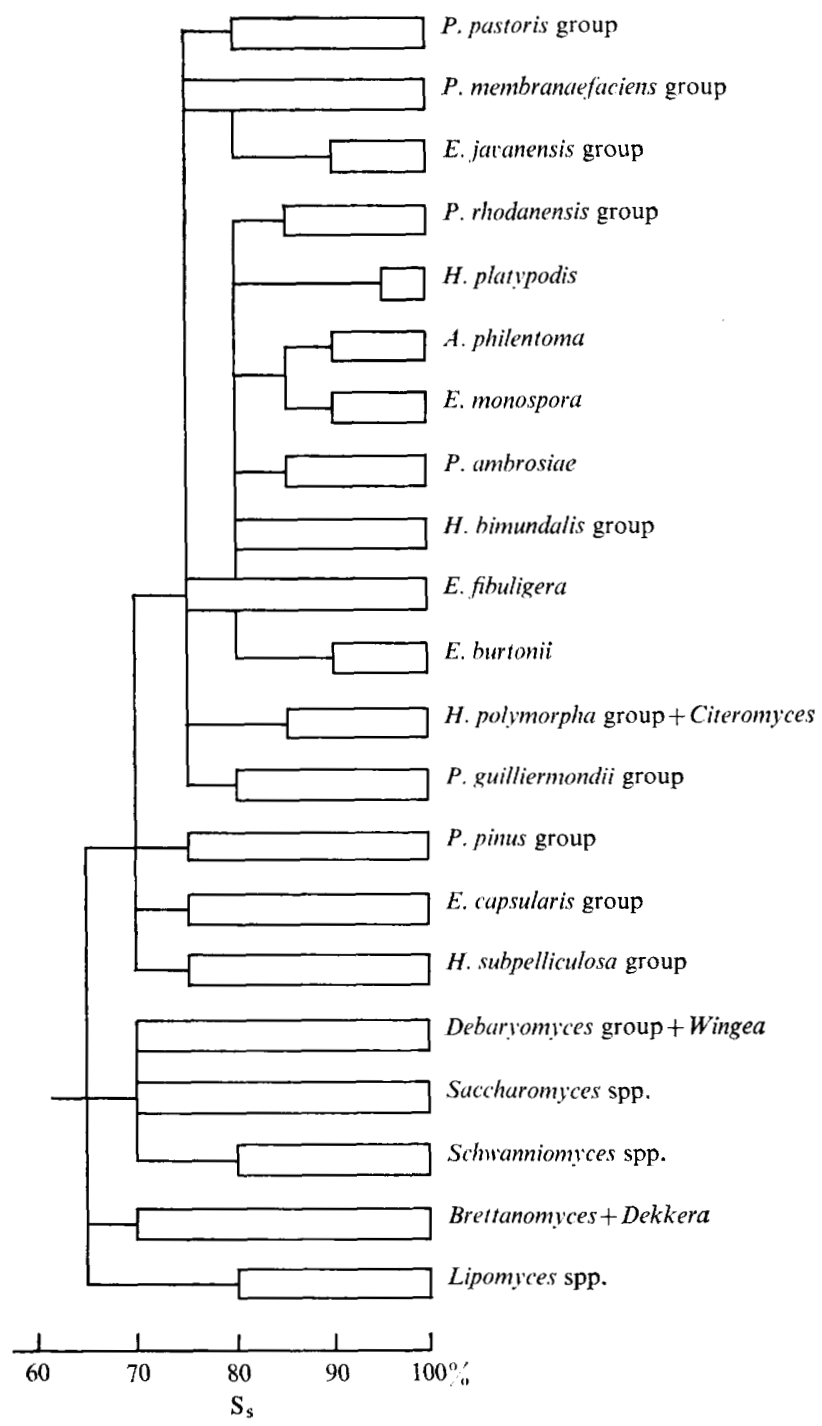

Fig. 3. Dendrogram of main taxonomic groups of the genera Ambrosiozyma, Brettanomyces, Citeromyces, Debaryomyces, Dekkera (included in Brettanomyces group), Endomycopsis, Hansenula, Lipomyces, Pachysolen (included in $\boldsymbol{H}$. polymorpha group), Pichia, Saccharomyces, Schwanniomyces and Wingea.

Fig. I. Taxonomic dendrogram of species of the genera Ambrosiozyma, Debaryomyces, Endomycopsis, Pichia, Schwanniomyces and Wingea, from analysis of standard descriptions of species.

Fig. 2. Taxonomic dendrogram of species of the genera Brettanomyces, Citeromyces, Dekkera, Hansenula, Lipomyces, Lodderomyces and Pachysolen, from analysis of standard descriptions of species. 


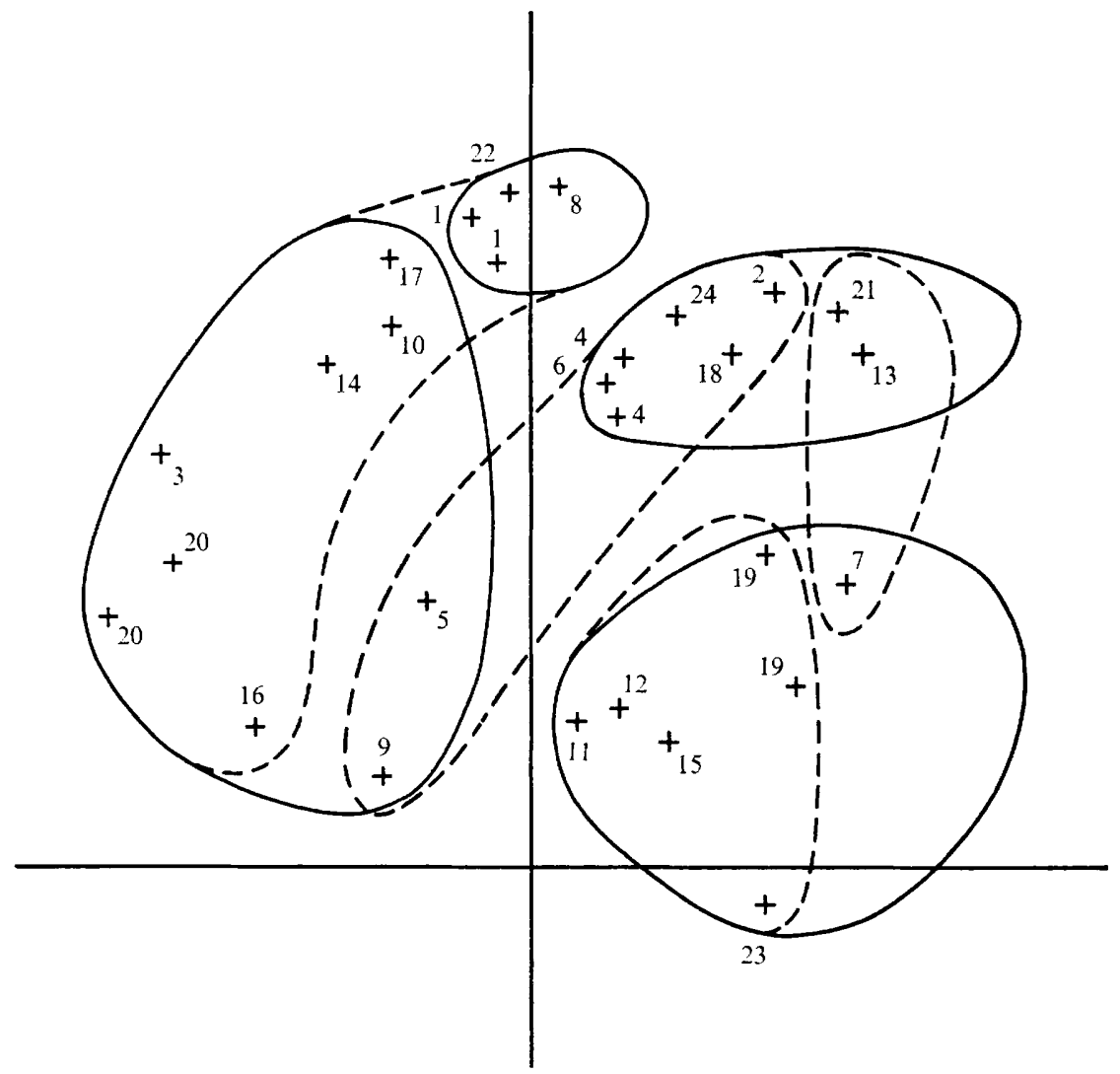

Fig. 4. Comparison of taxonomic groups of the genus Hansenula. _- Groups by Poncet (1970); - - groups by Fig. 2. Key to species: I, H. anomala; $2, H$. beckii; $3, H$. beijerinckii; $4, H$. bimundalis; $5, H$. californica $; 6, H$. canadensis; $7, H$. capsulata $; 8, H$. ciferri $; 9, H$. dimennae; I0, H. fabianii; I I, H. glucozyma; $\mathrm{I} 2, H$. henricii; $\mathrm{I} 3, H$. holstii ; 14, H. jadinii; $15, H$. minuta; $16, H$. mrakii; I 7, H. petersonii; I8, H. platypodis; 19, H. polymorpha; 20, H. saturnus; $21, H$. silvicola; 22, $H$. subpelliculosa; 23, $H$. wickerhamii ; $24, H$. wingei.

Kluyveromyces lactis, Saccharomyces cerevisiae, S. cidri, S. dairensis, S. delbrueckii, $S$. kluyveri (formerly Debaryomyces globosus according to Lodder \& Kreger-van Rij, 1952), S. montanus (D. mandshuricus Naganishi), S. rosei and $S$. rouxii, representing the Saccharomyces group, were compared with representatives of the main Hansenula, Pichia, Brettanomyces, Debaryomyces and Endomycopsis groups, and Lipomyces and Lodderomyces species. Three pairs were matched at $80 \%: S$. dairensis and Pichia membranaefaciens, $S$. kluyveri and $D$. tamarii, and $S$. rouxii and $D$. coudertii. Otherwise matches were at $70 \%$ or less, and the three results at a higher level were regarded as exceptions. Saccharomyces was most closely associated with the genera Debaryomyces and Schwanniomyces, at approx. $70 \%$ matching (Fig. 3).

\section{DISCUSSION}

Very few of the species in the present analysis were represented by strains in our culture collection, and standard descriptions by the contributors to Lodder's (1970) book provided the information for comparison of species. The good correlation between numerical analyses of standard descriptions of Kluyveromyces and Saccharomyces species and of actual strains 
(Campbell, 1972) suggested that standard descriptions alone would provide accurate information for the present series of analyses.

\section{The genera Ambrosiozyma, Endomycopsis, Hansenula and Pichia}

Our results of analyses of the genera Hansenula and Pichia confirmed Poncet's (I967, 1970) results in most respects. Fig. I suggests that Poncet's large groups A and C of the genus Pichia (Fig. I by Poncet, 1967) should be further subdivided. Poncet's (1970) and our analyses of the genus Hansenula also provided similar results, but the groups arranged by her factor analyses did not coincide exactly with clusters in our dendrogram, Fig. 2. Possibly the discrepancies, indicated in Fig. 4, are the result of Poncet's use of single strains, in contrast to our use of published standard descriptions, to represent large and variable species, but the two different forms of calculation must also account for some differences. It is interesting that Poncet's fig. 3 (1970) showed a difference between Hansenula saturnus and $H$. suaveolens (Klöcker) Dekker, now regarded as synonymous (Wickerham, I970a), and between $H$. polymorpha and $H$. angusta Teunisson et al., also synonyms at present.

The majority of species of Endomycopsis, Hansenula and Pichia formed an inseparable group (Fig. 3). Endomycopsis bispora, E. muscicola Nakase \& Komagata and E. platypodis, which assimilate nitrate as sole source of nitrogen, have been allocated to the genus Hansenula (Wickerham, I970a; Yarrow, 1972); in the case of Hansenula beckii and H. platypodis this is justified by their close associated with true Hansenula species in Fig. 2 and 3, but $H$. muscicola is related to other hansenulae at only $70 \%$ matching, and is equally closely related to nitrate-negative Endomycopsis and Pichia species. Endomycopsis monospora and the closely related species E. platypodis, Pichia ambrosiae and P. cicatricosa were transferred to the genus Ambrosiozyma by van der Walt (1972). While these species and Ambrosiozyma philentoma appeared as a distinct group at $80 \%$ matching in Fig. I, there is little justification for a separate genus since the species are equally closely related to other species not classified as Ambrosiozyma. Van der Walt's genus Ambrosiozyma is simply a subgroup of the species E. fibuligera (Fig. I).

Several new genera were proposed by von Arx (1972), but were not confirmed by our series of numerical analyses. Hormoascus platypodis (Baker \& Kreger-van Rij) von Arx (Endomycopsis platypodis) is related at $80 \%$ matching to species of Hansenula and Pichia, therefore Hormoascus platypodis is as unacceptable, and for the same reasons, as Ambrosiozyma platypodis (Baker \& Kreger-van Rij) van der Walt. Arthroascus javanensis (Klöcker) von Arx (E. javanensis) is related at $\mathrm{S}_{8} 80 \%$ to E. ovetensis and the Pichia membranaefaciens group, and is synonymous with $P$. nonfermentans Nakase. Nor was von Arx's suggestion of synonymy of Ambrosiozyma monospora (Saito) van der Walt (E. monospora) and P. crossotarsi Batra confirmed by numerical analysis of the standard descriptions provided by Kreger-van Rij (I970c) and Batra (I97I) respectively. Pichia crossotarsi and P. microspora Batra, which are synonymous at $90 \%$ matching, are shown in Fig. I as a distinct species from E. monospora. The status of a separate genus Guilliermondella, revived by von Arx (1972), is supported by numerical analysis; Guilliermondella selenospora Nadson \& Krassilnikov is related at only $75 \%$ matching to $E$. capsularis and could be a separate genus.

Current taxonomic practice favours the abolition of the generic name Endomycopsis (Wickerham, I970a; Batra, I97I ; van der Walt \& Scott, I97I $c$; von Arx, 1972; Yarrow, 1972). There is no clear separation between filamentous genera and pseudomycelial yeasts of the genera Hansenula and Pichia. Suggested definitions of genera by von Arx (1972) which concern the present paper are: no assimilation of nitrate, septate hyphae - Saccharomycopsis; no assimilation of nitrate, septate hyphae - Pichia; assimilation of nitrate, septate 
Table I. Comparison of published properties of Hansenula, Pichia and related genera

\begin{tabular}{|c|c|c|c|c|}
\hline & $\begin{array}{l}\text { Pmr } \\
\text { type }^{1}\end{array}$ & $\begin{array}{c}\mathrm{GC} \\
\text { proportion }^{2,3}\end{array}$ & $\begin{array}{c}\text { Serological } \\
\text { type }^{4}\end{array}$ & Antigenic structure ${ }^{3,5}$ \\
\hline Hansenula beijerinckii & II & $42 \cdot 7$ & - & $I, 2,14,16,17,20,21,22$ \\
\hline H. fabianii & Ioa & $44 \cdot 4-45 \cdot 6$ & - & - \\
\hline H. jadinii & IIf & $43 \cdot 2$ & $\mathrm{~F}$ & $\mathrm{I}, 2, \mathrm{I} 4, \mathrm{I} 6, \mathrm{I} 7$ \\
\hline H. anomala & roa & $35 \cdot 6-36 \cdot 6$ & $\mathrm{~F}$ & $I, 2,14,15,16,17,20$ \\
\hline H. ciferrii & roa & $32 \cdot 2$ & - & $I, 2,14,15,16,20$ \\
\hline H. subpelliculosa & Ioa & $33 \cdot 4-33 \cdot 9$ & $\mathrm{~F}$ & $I, 2,14,15,16,20$ \\
\hline H. mrakii & IId & $42 \cdot 0$ & $\mathrm{~F}$ & $1,2,14,15,16,17,20,21,22$ \\
\hline H. saturnus & roe/IIe & $42 \cdot 4-43 \cdot 7$ & $\mathrm{~F}$ & $\mathrm{I}, 2, \mathrm{I} 4,15,16,17,20,21,22$ \\
\hline H. californica & II a & $44 \cdot 0$ & - & - \\
\hline H. dimennae & II a & $42 \cdot 4-42 \cdot 9$ & - & - \\
\hline H. canadensis & IIg & $39 \cdot 3-40 \cdot 0$ & - & - \\
\hline$H$. wingei & Ioa & $39^{\circ} 0$ & - & - \\
\hline H. bimundalis & Ioa & $40 \cdot 0-42 \cdot 9$ & - & - \\
\hline H. beckii & IIg & $36 \cdot 3-36 \cdot 9$ & - & - \\
\hline H. platypodis & $9 \mathrm{~d}$ & $31 \cdot 5-36 \cdot 8$ & - & - \\
\hline H. capsulata & II h & $46 \cdot 8-47 \cdot I$ & - & - \\
\hline H. holstii & IIb & $36 \cdot 8-37 \cdot \mathrm{I}$ & - & - \\
\hline H. silvicola & Ioa & $34 \cdot I-35 \cdot I$ & - & $\mathrm{I}, 2, \mathrm{I} 4, \mathrm{I} 5, \mathrm{I} 6,20$ \\
\hline H. polymorpha & $9 b$ & $47 \cdot 8-48 \cdot 3$ & - & $\mathrm{I}, 2,5, \mathrm{II}, \mathrm{I} 7$ \\
\hline H. wickerhamii & $9 b$ & $45 \cdot 4$ & - & - \\
\hline H. glucozyma & $9 \mathrm{~b}$ & $45 \cdot \mathrm{I}$ & - & - \\
\hline H. henricii & $9 \mathrm{~b}$ & $49 \cdot 8-50 \cdot 2$ & - & - \\
\hline H. minuta & $9 \mathrm{~b}$ & $46 \cdot 8-47 \cdot 3$ & - & - \\
\hline H. nonfermentans & $9 \mathrm{~b}$ & $45 \cdot 6$ & - & - \\
\hline Pichia terricola & $9 \mathrm{a}$ & $36 \cdot 6-36 \cdot 8$ & - & $\mathrm{I}, 2,5, \mathrm{II}, \mathrm{I} 2,14,18,3 \mathrm{I}$ \\
\hline P. fluxuum & $9 \mathrm{~b}$ & $32 \cdot 2$ & - & $\mathrm{I}, 2,5, \mathrm{II}_{\mathrm{I}}$ \\
\hline P. saitoi & - & $32 \cdot 2$ & - & - \\
\hline P. dispora & - & $36 \cdot 3-37 \cdot I$ & - & - \\
\hline P. membranaefaciens & $9 \mathrm{a}$ & $4 I \cdot 5-42 \cdot 4$ & $\mathrm{~F}$ & $\mathrm{I}, 2,5$, II \\
\hline P. kluyveri & $9 \mathrm{~b}$ & $28 \cdot 3-28 \cdot 5$ & - & - \\
\hline P. fermentans & $9 \mathrm{c}$ & $42 \cdot 2$ & $\mathrm{~F}$ & $\mathrm{I}, 2,5, \mathrm{II}$ \\
\hline P. kudriavzevii & $9 \mathrm{c}$ & $38 \cdot 5$ & - & 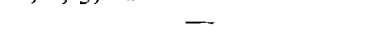 \\
\hline P. wickerhamii & - & $43 \cdot 2$ & 一 & 一 \\
\hline P. rhodanensis & $12 \mathrm{a}$ & $50 \cdot 2$ & - & - \\
\hline P. toletana & $6 a$ & $39 \cdot 3$ & $\mathrm{D}$ & - \\
\hline P. bovis & roa & $39 \cdot 8$ & - & - \\
\hline P. polymorpha & IIC & $33 \cdot 2$ & - & - \\
\hline P. pseudopolymorpha & $5 \mathrm{a}$ & Nor & - & - \\
\hline P. vini & $16 p$ & $36 \cdot 8-37 \cdot 3$ & D & - \\
\hline P. etchellsii & $17 \mathrm{k}$ & $38 \cdot 5$ & - & - \\
\hline Wingea robertsii & I5a & - & D & - \\
\hline Debaryomyces cantarellii & - & 33.9 & - & $\mathrm{I}, 2,3,5,13,14,15$ \\
\hline D. vanrijii & isa & $32 \cdot 4-32 \cdot 7$ & - & - \\
\hline D. castellii & $16 \mathrm{c}$ & $34 \cdot 4$ & - & $I, 2,3,5,13,14,15$ \\
\hline D. hansenii & $16 \mathrm{c}$ & $36 \cdot 6-37 \cdot 3$ & $\mathrm{D}$ & $\mathrm{I}, 2,3,4,9, \mathrm{I} 4$ \\
\hline D. marama & - & $36 \cdot 6$ & 一. & $\mathrm{I}, 2,3,4,9, \mathrm{I} 4$ \\
\hline
\end{tabular}

References: ${ }^{1}$ Gorin \& Spencer (1970); ${ }^{2}$ Meyer \& Phaff (1969); ${ }^{3}$ Nakase \& Komagata (1970, I971 $a, b$ ); ${ }^{4}$ Campbell (197I); ${ }^{5}$ Tsuchiya et al. (1965). 
hyphae present or absent-Hansenula. Those descriptions do not separate the genera adequately in terms of numerical analysis, although there is no suggestion of synonymy of the genera Hansenula and Pichia. Previous attempts to ignore the distinction between Hansenula and Pichia by assimilation of nitrate and to substitute other tests (reviewed by Wickerham, I970a, p. 236) did not greatly affect classification. However, Fig. 3 shows that species of different genera are closely related but not closely enough to suggest synonymy: Endomycopsis fibuligera and the Hansenula bimundalis, $H$. calfornica, Pichia ambrosiae, $P$. strasburgensis and $P$. toletana groups are related at $80 \%$ matching coefficient.

The majority of taxonomic deductions from numerical analyses (Fig. I, 2) were confirmed by previously published data. Proton magnetic-resonance ( $\mathrm{pmr}$ ) spectra of wall mannans (Gorin \& Spencer, I970), GC proportion in DNA bases (Meyer \& Phaff, I969; Nakase \& Komagata 1970, I97 $a, b$ ) and serological properties (Tsuchiya, Fukazawa \& Kawakita, I965; Campbell, I97I) of a selection of species are listed in Table I to support our classification. The few exceptions require comment: members of the Pichia membranaefaciens group, although related in pmr spectra and antigenic structure, vary over a wide range of GC proportions $(28 \cdot 3$ to $42 \cdot 2)$. Pichia rhodanensis, of GC proportion $50 \cdot 2 \%$, is in a group of GC 39.3 to $43.2 \%$, and Hansenula capsulata, GC proportion 46.8 to $47 \cdot \mathrm{I} \%$, is associated with $H$. holstii and $H$. silvicola, GC proportion $34 \cdot \mathrm{I}$ to $37 \cdot \mathrm{I} \%$. Otherwise, the GC proportions of species in taxonomic groups fall within a range of $\pm 2 \%$ of the mean value. It is generally true that species allocated by numerical analysis to the same taxonomic group were placed by Gorin \& Spencer (1970) in the same pmr type or in types which showed peaks of the spectra at $\operatorname{similar} \tau$ values thus indicating chemical similarity.

\section{The genera Brettanomyces and Dekkera}

Brettanomyces custersianus, B. abstinens Yarrow \& Ahearn and B. naardenensis Kolfschoten \& Yarrow were clearly separated and are therefore valid species. The remaining seven species of Brettanomyces and the two of Dekkera overlapped so extensively that they were regarded as a single species. The $5 \%$ difference between $B$. bruxellensis and Dekkera bruxellensis, and between $B$. intermedius and $D$. intermedia, was accounted for by properties of the spores of Dekkera species; this emphasizes earlier criticisms (Barnett, I960, 197I ; Campbell, I97I) of the use of spore properties in classification. The group is therefore defined as B. bruxellensis, of wider variation than at present. For computerized yeast identification (Campbell, 1973), two descriptions of invariable properties were required.

\section{The genera Citeromyces and Pachysolen}

Citeromyces matritensis and Pachysolen tannophilus are similar to Hansenula species (Wickerham, $\mathrm{I} 970 \mathrm{~b}, c$ ) but the $75 \%$ matching coefficient between $C$. matritensis and the most closely related species of Hansenula distinctly separates the genera. Unfortunately the form of the spores is the only obvious difference from Hansenula species. Wickerham's (1970 b) suggestion of a relationship between C. matritensis, Debaryomyces hansenii and Schwanniomyces occidentalis was not supported by our analyses (Fig. 3). Tsuchiya et al. (I965) demonstrated a close serological relationship (Table 2), but Gorin \& Spencer (1970) allocated the species to different pmr groups, with peaks at different $\tau$ values.

Analysis of strains of Pachysolen tannophilus, Hansenula capsulata, H. holstii and $H$. silvicola (Campbell, 197I) showed $80 \%$ matching coefficient, which suggested that $P$. tannophilus should be included in the genus Hansenula. Although Gorin \& Spencer (1970) indicated a difference between $P$. tannophilus and Hansenula species, it was not confirmed by analysis of the whole range of published properties (Fig. 2). To include P. tannophilus, 
the definition (Wickerham, I970a) of the genus Hansenula should be amended thus: 'Asci have the shape of the vegetative cells or are rod-shaped', deleting the section '. . . and are not rod-shaped as in the nitrate-positive genus Pachysolen'.

\section{The genera Debaryomyces and Wingea}

The complete overlap of Debaryomyces, Wingea and five species of Pichia suggests that these five species were wrongly allocated to the genus Pichia, or that there is no justification for a separate genus Debaryomyces. Kreger-van Rij (I970a,b) described the difficulty of allocating species to the correct genus, and indeed the difficulty of defining each genus. A distinction was only possible by electron microscopy of sporing cultures, and even so, intermediate forms occurred which were arbitrarily placed in the genus Pichia as Pichia fluxuum and P. terricola. Although species in Fig. I which could be allocated to a separate genus Debaryomyces were distinct from the remaining species of Pichia, there were no properties which satisfactorily distinguished the two genera.

Available data on pmr spectra, GC proportions and serology (Table I) confirm that the genera Debaryomyces, Pichia and Wingea form a homogeneous group. Pichia pseudopolymorpha, of pmr group $5 a$, is not as anomalous as first appears, since the peaks of spectra $5 \mathrm{a}$ and II C ( $P$. polymorpha) are in the same $\tau$ positions (Gorin \& Spencer, I970). With the exception of Debaryomyces tamarii, which is taxonomically different in Fig. I, all species of the $D$. hansenii/P. polymorpha group are of GC proportion $32 \cdot 4$ to 38.5 .

There appears to be no convenient alternative to a single genus Pichia, to which the definition by Kreger-van Rij (I970a) is applicable on insertion of the words 'The spores have smooth or warty walls' and deleting 'The spores are generally smooth; they may have warts formed exclusively by the outer layer of the spore wall.' The definition should also state that 'The spores are spherical, hat- or Saturn-shaped or lentiform . . .' to include van der Walt's (I970c) genus Wingea, for which, according to our results, there is no justification as a separate genus. Its single species is described below as Pichia robertsii van der Walt.

\section{The genera Lipomyces, Lodderomyces and Schwanniomyces}

These genera are sufficiently different to remain separate from the other genera of this analysis. The three species of Lipomyces (Slooff, 1970) are mutually related at $90 \%$ matching, but vary over approximately $20 \%$ of properties. Therefore the three species may be described as a single species, Lipomyces starkeyi, of wider variation than at present described, and as two units for computerized identification (Table I). In the genus Schwanniomyces there is insufficient difference between Schwanniomyces alluvis and $S$. castellii and between $S$. occidentalis and $S$. persoonii to justify separate species, and a reduction of the genus to two species is suggested. This is in accord with Gorin \& Spencer's (I970) results; all were placed in group 15 .

\section{List of synonyms}

The analyses of standard descriptions of species have indicated the following amendments to the classification by Lodder (1970) of the genera Brettanomyces, Debaryomyces, Dekkera, Endomycopsis, Hansenula, Lipomyces, Pachysolen, Pichia, Schwanniomyces and Wingea. The genera Citeromyces and Lodderomyces, also analysed in the present paper, are unchanged. 
Genus Brettanomyces Kufferath \& v. Laer.

The genus contains four species:

(I) Brettanomyces abstinens Yarrow \& Ahearn (1971)

(2) Brettanomyces bruxellensis Kufferath \& v. Laer

Synonyms: B. anomalus Custers, B. claussenii Custers, B. custersii Florenzano, B. intermediis (Krumbholz \& Tauschanoff) v.d. Walt \& v. Kerken, B. lambicus Kufferath \& v. Laer and synonyms of $B$. anomalus, B. bruxellensis, B. claussenii, B. intermedius listed by van der Walt (1970).

(3) Brettanomyces custersianus v. d. Walt

(4) Brettanomyces naardenensis Kolfschoten \& Yarrow (1970)

Since it is customary to allocate sporing and non-sporing yeasts to separate genera, we reluctantly recognize the genus Dekkera v. d. Walt. The genus contains one species:

(I) Dekkera bruxellensis v. d. Walt

Synonym: $D$. intermedia v. d. Walt.

Genus Hansenula Sydow \& Sydow

The genus contains 20 species, of which nine are as listed by Wickerham (1970a):

(2) Hansenula beckii Wickerham

(3) Hansenula beijerinckii v. d. Walt

(6) Hansenula capsulata Wickerham

(8) Hansenula holstii Wickerham

(13) Hansenula platypodis de Morais \& Maia

(14) Hansenula polymorpha de Morais \& Maia

(16) Hansenula silvicola Wickerham

(I7) Hansenula subpelliculosa Bedford

(20) Hansenula wickerhamii Capriotti

The following amendments are suggested to the list of species by Wickerham (1970a).

(I) Hansenula anomala (Hansen) Sydow \& Sydow

Synonyms: $H$. ciferrii Lodder and synonyms of $H$. anomala var. anomala, $H$. anomala var. schneggii (Weber) Wickerham and H. ciferrii listed by Wickerham (1970a).

(4) Hansenula californica (Lodder) Wickerham

Synonyms: H. bimundalis Wickerham \& Santa Maria var. bimundalis, H. bimundalis var. americana Wickerham, $H$. winge $i$ Wickerham and synonyms of $H$. bimundalis, $H$. californica and $H$. wingei listed by Wickerham (1970a).

(5) Hansenula canadensis Wickerham

Synonyms: $H$. dimennae Wickerham and Azymohansenula canadensis (Wickerham) Novak \& Zsolt, Acta bot. hung. (I961), 7, 93.

(7) Hansenula dryadoides Scott \& v. d. Walt (1971 $b$ )

(9) Hansenula jadinii (Sartory et al.) Wickerham

Synonyms: $H$. fabianii Wickerham, $H$. petersonii Wickerham and synonyms of $H$. fabianii and H. jadinii listed by Wickerham (1970a).

(Io) Hansenula minuta Wickerham

Synonyms: $H$. glucozyma Wickerham, $H$. henricii Wickerham and $H$. nonfermentans Wickerham.

(II) Hansenula muscicola (Nakase \& Komagata) Yarrow (I972)

(I2) Hansenula philodendra Scott \& v. d. Walt (I970a)

(I5) Hansenula saturnus (Klöcker) Sydow \& Sydow 
Synonyms: $H$. mrakii Wickerham, $H$. saturnus var. saturnus, $H$. saturnus var. subsufficiens Wickerham and synonyms of $H$. saturnus listed by Wickerham (I970a).

(I8) Hansenula sydowiorum Scott \& v. d. Walt (1970b)

(19) Hansenula tannophilus (Boidin \& Adzet) Campbell nov.comb.

Basionym: Pachysolen tannophilus Boidin \& Adzet, Bull Soc. mycol. Fr. (1957), 73, 33 I. Synonym: P. pelliculatus Boidin \& Adzet, Bull. Soc. mycol. Fr. (1957), 73, 33 I.

Genus Lipomyces Lodder \& Kreger-v. Rij

The genus contains one species:

(I) Lipomyces starkeyi Lodder \& Kreger-v. Rij

Synonyms: L. kononenkoae Nieuwdorp et al., L. lipofer Lodder \& Kreger-v. Rij and synonyms of $L$. lipofer listed by Slooff (1970).

Genus Pichia Hansen

The genus contains 4I species, of which I6 are as listed by Kreger-van Rij (I970a):

(I) Pichia acaciae v. d. Walt

(3) Pichia angophorae Miller \& Barker

(7) Pichia chambardii (Ramirez \& Boidin) Phaff

(I I) Pichia farinosa (Lindner) Hansen

(I5) Pichia guilliermondii Wickerham

(I7) Pichia haplophila Shifrine \& Phaff

(19) Pichia kudriavzevii Boidin et al.

(2 I) Pichia media Boidin et al.

(25) Pichia ohmeri (Etchells \& Bell) Kreger-v. Rij

(27) Pichia pastoris (Guilliermond) Phaff

(28) Pichia pijperi v. d. Walt \& Tscheuschner

(30) Pichia pseudopolymorpha Ramirez \& Boidin

(33) Pichia salictaria Phaff et al.

(35) Pichia scolyti (Phaff \& Yoneyama) Kreger-v. Rij

(37) Pichia stipitis Pignal

(40) Pichia trehalophila Phaff et al.

The following amendments are suggested to the list of species by Kreger-van Rij (I970a):

(2) Pichia ambrosiae v. d. Walt \& Scott (1971 $a$ )

(4) Pichia burtonii Boidin et al., Bull. Soc. mycol. Fr. (1964), 8o, 396

Synonyms: Endomycopsis burtonii (Boidin et al.) Kreger-v. Rij and synonyms of $E$. burtonii in Lodder, The Yeasts (1970), p. 174.

(5) Pichia cantarellii (Capriotti) Campbell nov.comb.

Basionym: Debaryomyces cantarellii Capriotti, Arch. Mikrobiol. I96ı, 39, 23.

Synonym: D. phaffii Capriotti, J. Bact. (196I), 82, 326.

(6) Pichia castellii (Capriotti) Campbell nov.comb.

Basionym: Debaryomyces castellii Capriotti, Arch. Mikrobiol. (I958), 28, 344.

Synonym: Zymodebaryomyces castellii (Capriotti) Novak \& Zsolt, Acta bot. hung. (I96I), 7, 93 .

(8) Pichia coudertii (Saëz) Campbell nov.comb.

Basionym: Debaryomyces coudertii Saëz, Bull. mens. Soc. linn. Lyon (I960), 29, 288.

(9) Pichia crossotarsi Batra (1971)

Synonym: P. microspora Batra (1971). 
(Io) Pichia dispora (Dekker) Kreger-v. Rij.

Synonyms: P. besseyi Kurtzman \& Wickerham, P. delftensis Beech, P. saitoi Kodama et al. and synonyms of $P$. dispora listed by Kreger-van Rij (1970a).

(I2) Pichia fasciculata (Batra) Boidin et al., Bull. Soc. mycol. Fr. (1965), 81, 5

Synonyms: Endomycopsis monospora Saito, and synonyms of E. monospora in Lodder, The Yeasts (1970), p. I89.

(13) Pichia fibuligera (Lindner) Boidin et al., Bull. Soc. mycol. Fr. 1964, 80, 396

Synonyms: Endomycopsis fibuligera (Lindner) Dekker, and synonyms of E. fibuligera in Lodder, The Yeasts (1970), p. I8I.

(14) Pichia fluxuum (Phaff \& Knapp) Kreger-v. Rij

Synonyms: $P$. terricola $v$. d. Walt and synonyms of $P$. fluxuum and $P$. terricola listed by Kreger-van Rij (I970a).

(I6) Pichia hansenii (Zopf) Campbell nov.comb.

Basionym: Saccharomyces hansenii Zopf, Ber. dt. bot. Ges. (I 889), 7, 94.

Synonyms: Debaryomyces hansenii (Zopf) Lodder \& Kreger-v. Rij in The Yeasts (1952), p. 270, and synonyms in Lodder, The Yeasts 1970, p. 140.

(18) Pichia heimii Pignal (1970)

(20) Pichia marama (di Menna) Phaff, Antonie van Leeuwenhoek (I956), 22, I I3.

Synonyms: Debaryomyces marama di Menna and Zymodebaryomyces marama (di Menna) Novak \& Zsolt in Lodder, The Yeasts i970, p. I46.

(22) Pichia melissophila v. d. Walt \& v. d. Klift (I972)

(23) Pichia membranaefaciens Hansen

Synonyms: $P$. fermentans Lodder, $P$. kluyveri Bedford and synonyms of $\boldsymbol{P}$. fermentans, $P$. kluyveri and P. membranaefaciens listed by Kreger-van Rij (I970a).

(24) Pichia mucosa Wickerham \& Kurtzman (197I)

(26) Pichia pastoris (Guilliermond) Phaff

Synonyms: $P$. quercuum Phaff \& Knapp and synonyms of $P$. pastoris and $P$. quercuum listed by Kreger-van Rij (1970a).

(29) Pichia polymorpha Klöcker

Synonyms: Debaryomyces vanrijii (v. d. Walt \& Tscheuschner) Abadie et al. and synonyms of $D$. vanrijii and $P$. polymorpha listed by Kreger-van Rij $(1970 a, b)$.

(3I) Pichia rhodanensis (Ramirez \& Boidin) Phaff

Synonyms: $P$. bovis v. Uden \& do Carmo-Sousa, $P$. toletana (Socias et al.) Kregerv. Rij, P. wickerhamii (v. d. Walt) Kreger-v. Rij, P. xylopsoci v. d. Walt \& Scott and synonyms of $P$. bovis, $P$. rhodanensis, $P$. toletana and $P$. wickerhamii listed by Kreger-van Rij (1970a).

(32) Pichia robertsii v. d. Walt, Antonie van Leeuwenhoek (1959), 25, 337

Synonym: Wingea robertsii (v. d. Walt) v. d. Walt, Antonie van Leeuwenhoek (1967), 33, 97.

(34) Pichia sargentensis Wickerham \& Kurtzman (1971)

(36) Pichia spartinae Ahearn et al. (1970)

(38) Pichia strasburgensis (Ramirez \& Boidin) Phaff

Synonyms: $P$. onychis Yarrow and synonyms of $P$. strasburgensis listed by Kreger-van Rij (I970a).

(39) Pichia tamarii (Ohara \& Nonomura) Campbell nov.comb.

Basionym: Debaryomyces tamarii Ohara \& Nonomura, J. agric. chem. Soc. Japan (1954), 28, 337.

(4I) Pichia vini (Zimmermann) Phaff 
Synonyms: $P$. etchellsii Kreger-v. Rij, $P$. vini var. vini, $P$. vini var. melibiosi Santa Maria and synonyms of $P$. etchellsii and $P$. vini listed by Kreger-van Rij (1970a).

\section{Genus Schwanniomyces Klöcker}

The genus contains two species:

(I) Schwanniomyces castellii Capriotti Synonym: S. alluvius Phaff et al.

(2) Schwanniomyces occidentalis Klöcker

Synonym: S. persoonii v. d. Walt.

\section{REFERENCES}

Abadie, F., Pignal, M. C. \& JacoB, J. L. (1963). Les levures à spores verruqueuses. Bulletin de la Société Mycologique de France 79, 16-70.

Ahearn, D. G., Yarrow, D. \& MeYers, S. P. (1970). Pichia spartinae sp.n. from Louisiana marshland habitats. Antonie van Leeuwenhoek 36, 503-508.

von ARX, J. A. (1972). On Endomyces, Endomycopsis and related yeast-like fungi. Antonie van Leeuwenhoek 38, 289-309.

BARnett, J. A. (1960). Comparative studies on yeasts. Nature, London 186, 449-45I.

BARNETt, J. A. (I97I). Selection of tests for identifying yeasts. Nature, London 232, 22 I-223.

Batra, L. R. (197I). Two new hemiascomycetes: Pichia crossotarsi and P. microspora. Mycologia 63, 994-100I.

CAMPBeLL, I. (1970). Comparison of serological and physiological classification of the genus Saccharomyces. Journal of General Microbiology 63, I89-198.

CAMPBell, I. (197I). Numerical taxonomy of various genera of yeasts. Journal of General Microbiology 67, 223-23I.

CAmpBelL, I. (1972). Numerical analysis of the genera Saccharomyces and Kluyveromyces. Journal of General Microbiology 73, 279-30I.

CAmprell, I. (I973). Computer identification of yeasts of the genus Saccharomyces. Journal of General Microbiology 77, 127-135.

Dwidjoseputro, D. \& WolF, F. T. (1970). Microbiological studies of Indonesian fermented foodstuffs. Mycopathologia et Mycologia Applicata 4I, 2 I I-222.

GoRIN, P. A. J. \& SPENCER, J. F. T. (1970). Proton magnetic resonance spectroscopy - an aid in identification and chemotaxonomy of yeasts. Advances in Applied Microbiology 13, 25-89.

Kolfschoten, G. A. \& Yarrow, D. (I970). Brettanomyces naardenensis, a new yeast from soft drinks. Antonie van Leeuwenhoek 36, 458-460.

Kreger-van RiJ, N. J. W. (1969). Taxonomy and systematics of Yeasts. In The Yeasts, vol. I, pp. 5-78. Edited by A. H. Rose and J. S. Harrison. London and New York: Academic Press.

Kreger-VAn RiJ, N. J. W. (1970a). Genus 15. Pichia Hansen. In The Yeasts, a Taxonomic Study, 2nd edn, pp. 455-554. Edited by J. Lodder. Amsterdam and London: North Holland Publishing Co.

Kreger-van RiJ, N. J. W. (1970b). Genus 3. Debaryomyces Lodder et Kreger-van Rij nom. conserv. In The Yeasts, a Taxonomic Study, 2nd edn, pp. 129-156. Edited by J. Lodder. Amsterdam and London: North Holland Publishing Co.

Kreger-VAn Ris, N. J. W. (1970c). Genus 5. Endomycopsis Dekker. In The Yeasts, a Taxonomic Study, and edn, pp. I66-208. Edited by J. Lodder. Amsterdam and London: North-Holland Publishing Co.

Kurtzman, C. P. \& Wickerham, L. J. (1972). Pichia besseyi sp.n. Antonie van Leeuwenhoek 38, 49-52.

Lodder, J. (1970). The Yeasts, a Taxonomic Study, 2nd edn. Amsterdam and London, North-Holland Publishing Co.

Lodder, J. \& Kreger-Van RiJ, N. J. W. (1952). The Yeasts, a Taxonomic Study. Amsterdam: NorthHolland Publishing Co.

Meyer, S. A. \& Phaff, H. J. (1969). Deoxyribonucleic acid base composition in yeasts. Journal of Bacteriology $97,52-56$.

NAKASE, T. (I97I). Four new yeasts found in Japan. Journal of General and Applied Microbiology 17, 469-478.

NaKase, T. \& Komagata, K. (1966). New yeasts, Endomycopsis muscicola and Pichia zaruensis. Journal of General and Applied Microbiology 12, 347-352. 
NAKASE, T. \& Komagata, K. (1970). Significance of DNA base composition in the classification of yeast genus Pichia. Journal of General and Applied Microbiology 16, $511-521$.

NAKase, T. \& Komagata, K. (I97I $a$ ). Significance of DNA base composition in the classification of yeast genus Debaryomyces. Journal of General and Applied Microbiology 17, 43-50.

Nakase, T. \& Komagata, K. (I97 I $b$ ). Further investigation on the DNA base composition of the genus Hansenula. Journal of General and Applied Microbiology 17, 77-84.

Phaff, H. J. (1970). Genus 20. Schwanniomyces Klöcker. In The Yeasts, a Taxonomic Study, 2nd edn, pp. 756-766. Edited by J. Lodder. Amsterdam and London: North-Holland Publishing Co.

Pignal, M.-C. (1970). A new species of yeast isolated from decaying insect-invaded wood. Antonie van Leeuwenhoek 36, 525-529.

Poncet, S. (1967). A numerical classification of yeasts of the genus Pichia Hansen by a factor analysis method. Antonie van Leeuwenhoek 33, 345-358.

Poncet, S. (I970). Le genre Hansenula, H. et P. Sydow (Ascomycetes, Endomycetaceae). Application d'une methode d'analyse factorielle à la taxinomie de ce groupe. Annales de l'Institut Pasteur rig, 232-248.

DE QueIroz, L. A. (1970). Pichia faecalis nov.comb. Mycopathologica et mycologia applicata 4r, 327-329.

ScotT, D. B. \& VAN DER WALT, J. P. (1970a). Three new yeasts from South African insect sources. Antonie van Leeuwenhoek 36, 389-396.

SCOTT, D. B. \& VAN DER WALT, J. P. (1970 b). Hansenula sydowiorum sp.n. Antonie van Leeuwenhoek $\mathbf{3}^{6}$, $45-48$.

SCOTT, D. B. \& VAN DER WALT, J. P. (I97I $a$ ). Pichia cicatricosa sp.n., a new auxiliary ambrosia fungus. Antonie van Leeuwenhoek 37, 177-183.

SCOTT, D. B. \& VAN DER WALT, J. P. (I97I $b$ ). Hansenula dryadoides sp.n., a new species from South African insect sources. Antonie van Leeuwenhoek 37, 171-175.

Slooff, W. C. (1970). Genus 9. Lipomyces Lodder et Kreger-van Rij. In The Yeasts, a Taxonomic Study, 2nd edn, pp. 379-402. Edited by J. Lodder. Amsterdam and London: North-Holland Publishing Co.

Sneath, P. H. A. (1972). Computer taxonomy. In Methods in Microbiology, vol. 7 A, pp. 29-98. Edited by J. R. Norris and D. W. Ribbons, London and New York: Academic Press.

Tsuchiya, T., Fukazawa, Y. \& Kawakita, S. (1965). Significance of serological studies on yeasts. $M y c o-$ pathologia et mycologia applicata 26, I-15.

VAN DeR WALT, J. P. (1970a). Genus 22. Wingea v. d. Walt. In The Yeasts, a Taxonomic Study, 2nd edn, pp. 772-775. Edited by J. Lodder. Amsterdam and London: North-Holland Publishing Co.

VAN DER WALT, J. P. (1970 b). Genus I. Brettanomyces Kufferath et van Laer. In The Yeasts, a Taxonomic Study, 2nd edn, pp. 863-892. Edited by J. Lodder. Amsterdam and London: North-Holland Publishing Co.

VAN Der Walt, J. P. (1970c). Genus 4. Dekkera van der Walt. In The Yeasts, a Taxonomic Study, 2nd edn, pp. I 57-I65. Edited by J. Lodder. Amsterdam and London: North-Holland Publishing Co.

VAN DER WALT, J.P. (I970d). Genus IO. Lodderomyces van der Walt. In The Yeasts, a Taxonomic Study, 2nd edn, pp. 403-407. Edited by J. Lodder. Amsterdam and London: North-Holland Publishing Co.

VAN DER WALT, J.P. (1972). The yeast genus Ambrosiozyma gen.nov. (Ascomycetes). Mycopathologia et mycologia applicata 46, 305-3I6.

VAN DER WALT, J. P. \& VAN DER KLIFT, W. C. (1972). Pichia melissophila sp.n., a new osmotolerant yeast from apiarian sources. Antonie van Leeuwenhoek 38, 36I-364.

VAN Der WALt, J. P. \& ScotT, D. B. (1971 a). Pichia ambrosiae sp.n., a new auxiliary ambrosia fungus. Antonie van Leeuwenhoek 37, 1 5-20.

VAN DeR Walt, J. P. \& ScotT, D. B. (I971 b). Pichia xylopsoci, a new yeast from South African insect sources. Mycopathologia et mycologia applicata 44, $32 \mathrm{I}-324$.

VAN DER WALT, J. P. \& SCOTT, D. B. (I97I c). The yeast genus Saccharomycopsis Schiönning. Mycopathologia et mycologia applicata 43, 279-288.

Wickerham, L. J. (I970a). Genus 7. Hansenula H. et P. Sydow. In The Yeasts, a Taxonomic Study, 2nd edn, pp. 226-315. Edited by J. Lodder. Amsterdam and London: North-Holland Publishing Co.

Wickerham, L. J. (1970 b). Genus I. Citeromyces Santa Maria. In The Yeasts, a Taxonomic Study, 2nd edn, pp. 12 I-I 27. Edited by J. Lodder. Amsterdam and London: North-Holland Publishing Co.

Wickerham, L. J. (1970c). Genus 14. Pachysolen Boidin et Adzet. In The Yeasts, a Taxonomic Study, 2nd edn, pp. 448-454. Edited by J. Lodder. Amsterdam and London: North-Holland Publishing Co.

Wickerham, L. J. \& Kurtzman, C. P. (I97I). Two new Saturn-spored species of Pichia. Mycologia 63, IOI3-IOI8.

YARROw, D. (1972). Four new combinations in yeasts. Antonie van Leeuwenhoek 38, 357-360.

YARrow, D. \& AHEARN, D. G. (1971). Brettanomyces abstinens sp.n. Antonie van Leeuwenhoek 37, 296-298. 